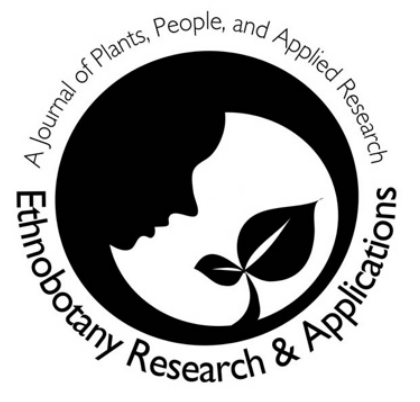

\title{
Traditional uses, phytochemistry and biological activities of Roscoea purpurea Sm.
}

\author{
Hari Prasad Devkota and Deepak Timalsina
}

\author{
Correspondence \\ Hari Prasad Devkota ${ }^{1, *}$ and Deepak Timalsina ${ }^{2}$ \\ ${ }^{1}$ Graduate School of Pharmaceutical Sciences, Kumamoto University, 5-1 Oe-honmachi, Chuo-Ku, Kumamoto 862- \\ 0973, Japan \\ ${ }^{2}$ Central Department of Chemistry, Tribhuvan University, Kirtipur, Kathmandu, Nepal \\ ${ }^{*}$ Corresponding Author: devkotah@kumamoto-u.ac.jp
}

Ethnobotany Research \& Applications 22:42 (2021)

\section{Reviews}

\begin{abstract}
Background. Roscoea purpurea Sm. (Zingiberaceae) is an important Himalayan plant used as tonic and for the treatment of various diseases.

Methods. The scientific information about the traditional uses, bioactive compounds, and biological activities were collected from the published research articles, books, and online scholarly databases such as Scopus, SciFinder and PubMed.
\end{abstract}

Results. R. purpurea is a valuable medicinal plant in the traditional medicinal system Ayurveda and is also locally used for the treatment of diabetes, urinary troubles, etc. Various bioactive compounds including phenolic acids, flavonoids and diterpenoids are reported mainly from the rhizomes. The extracts and compounds obtained from the rhizomes showed antioxidant, antimicrobial, cytotoxic and oxidative DNA damage protecting activities.

Conclusion: The study highlighted the traditional uses, bioactive compounds, and biological activities of $R$. purpurea. Published scientific articles suggest that the rhizomes are rich in bioactive compounds with pharmacological importance. Rhizomes can be a potential source for the development of functional foods and nutritional products. As most of the bioactivity analyses were based on in-vitro assays, future studies should focus more on in vivo and clinical studies.

Keywords. Roscoea, kakoli, rasgari, antioxidant, phenolic acids, flavonoids

\section{Background}

Zingiberaceae family consists of about 50 genera and about 1600 aromatic perennial herbs distributed over tropical Africa, America, and Asia (Christenhusz \& Byng 2016). Many species are widely used as food and nutritional products and for the treatment of cold, digestive problems, inflammation, pain, respiratory diseases, etc. (Devkota et al. 2021, Tushar et al. 2010, Lakhan et al. 2015, Timalsina et al. 2021).

Roscoea is one of the important genera of Zingiberaceae consisting of about 22 herbaceous plant species having diverse medicinal uses (Dhyani et al. 2020, Zhao et al. 2017). Roscoea purpurea Sm. (Syn. Roscoea procera Wall.) is 
a Himalayan perennial rhizomatous herb about 20-40 cm tall (Fig. 1), commonly known as rasgari, katare, in Nepal and kakoli, ksheera, karnika, vaysasha, and vayasoli in India (Ghimire et al. 2021, Watanabe et al. 2013, Misra et al. 2015). It is widely distributed in the mountainous region of Nepal, India and Bhutan at about 1520-3100 m (Zhao et al. 2017, Paudel et al. 2015, Watanabe et al. 2013). It is one of the Astavarga plants used as tonic in many Ayurvedic formulations such as Chyawanprash (Kaur et al. 2020, Miyazaki et al. 2014, Acharya et al. 2012). Traditionally, rhizomes are used in the treatment of various diseases and symptoms such as fever, wound, urinary troubles, diarrhea and dysentery (Rawat et al. 2014, Kumari et al. 2011). Few scientific studies about bioactive compounds and evaluation of bioactivities have been reported in recent years. However, there is no detailed review published on $R$. purpurea regarding its traditional uses, bioactive compounds and biological activities as per our knowledge. Thus, the main aim of this article was to collect and analyze the published information about traditional use, phytochemistry and biological activities of $R$. purpurea.
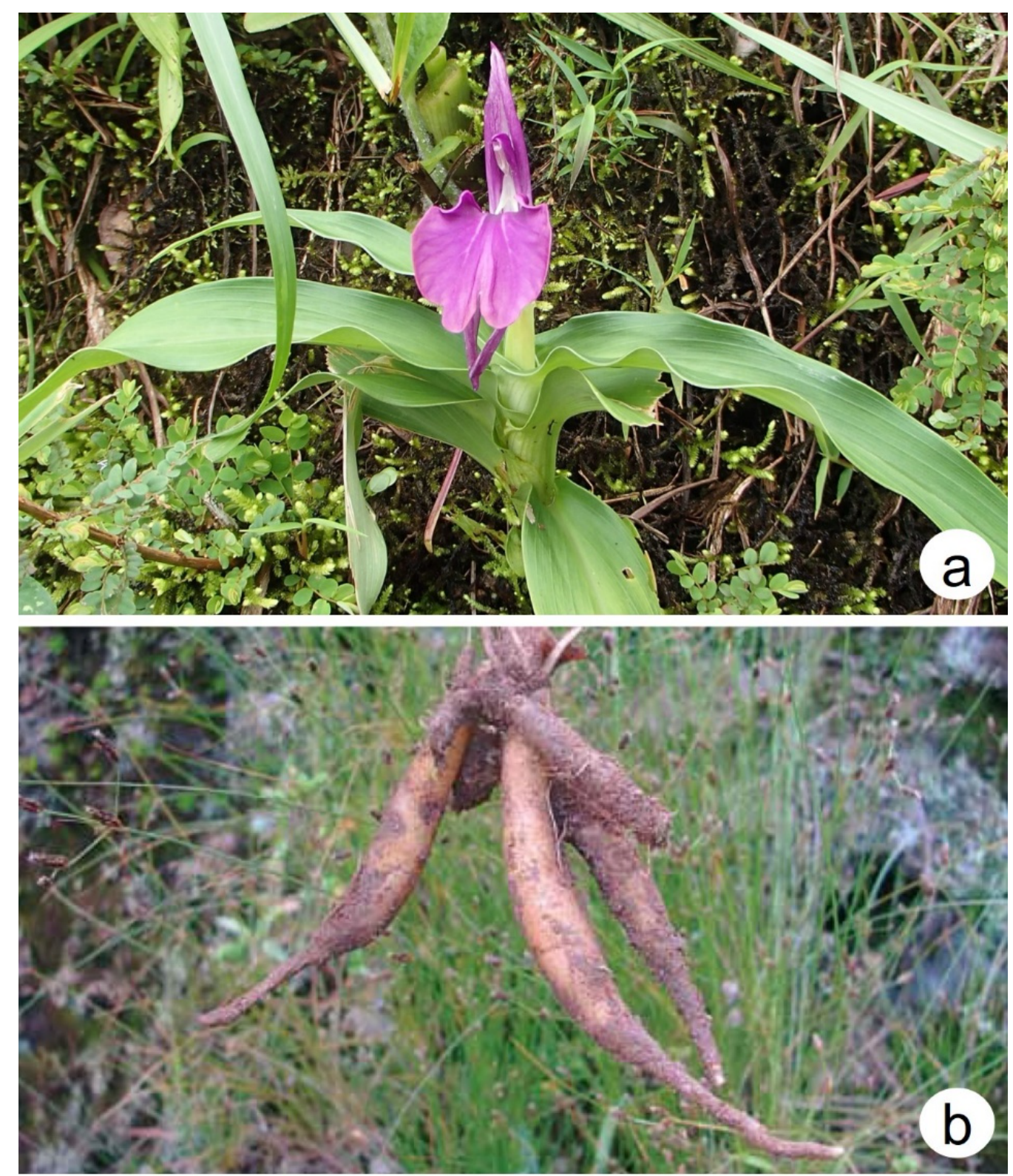

Figure 1. Photographs of aerial parts (a) and rhizomes (b) of $R$. purpurea. [Figure (b) was reproduced from Watanabe et al. 2013].

\section{Materials and Methods}

The relevant scientific information of $R$. purpurea was collected from published articles, books and various scholarly databases including SciFinder, PubMed, Scopus and Google Scholar by using the keywords such as Roscoea pupurea, Roscoea procera, kakoli, chemical constituents and biological activities. 


\section{Traditional uses}

The rhizome known as kakoli is one of the important Astavarga plants and it is used as tonic in many Ayurvedic formulations such as Chyawanprash (Kaur et al. 2020, Miyazaki et al. 2014, Singh 2006). It is reported to have antirheumatic, febrifuge, galactagogic, hemostatic, expectorant, stimulant, diuretic, sweet and cooling properties (Acharya et al. 2012). Rhizomes are widely used as a tonic, aphrodisiac, and remedy for wounds and urinary troubles in traditional medicine in Nepal (Watanabe et al. 2013, Kunwar \& Adhikari 2005). The powder of rhizome mixed with orange rind powder is reported to be used to treat bronchitis and asthma. Similarly, clarified butter processed with this powder is taken to treat cephalic diseases, stomatitis, gouts, emaciation, etc. (Acharya et al. 2012). The decoction prepared from the rhizomes is used to treat diarrhea, dysentery, and impotency (Rawat et al. 2014). Rhizomes are also used to treat diabetes, diarrhea, hypertension, inflammation, jaundice, and other ailments (Shah 2019, Rawat et al. 2016a, 2016b, 2016c, Misra et al. 2015, Kumari et al. 2011).

\section{Phytochemistry}

Various bioactive chemical constituents of different chemical classes such as phenolic acids, flavonoids and diterpenoids have been reported from $R$. purpurea (Table 1, Fig. 2). The nutritional components and phytochemicals of the rhizomes were analyzed and the results showed the presence of nutritional components such as fiber (28.1\%), oil (3.5\%), protein $(3.46 \%)$ and starch (0.84\%). Phytochemical screening of powder of the tuber showed the presence of carbohydrate, phenolics, flavonoids, saponins, tannins, glycosides, proteins, and alkaloids. Total phenolics and flavonoids contents in the methanol extract of rhizomes were found to be about $14 \mathrm{mg}$ gallic acid equivalent/g and $12 \mathrm{mg}$ quercetin equivalent/g, respectively (Misra et al. 2015). Rawat et al. (2014) reported the contents of various nutritional components such as thiamine, tannins, alkaloids, phenols, flavonoids, riboflavin, fat, minerals, and fibers in rhizomes. Rawat et al. (2016a) also reported the analysis of geographical and environmental variation in phenolic compounds and antioxidant activity. Among the various solvent extracts of the rhizomes i.e. water, methanol, ethanol, acetone and hexane extracts, methanol, ethanol and acetone extracts had higher contents of total phenolic and flavonoid compounds (Rawat et al. 2016c)

Table 1. Bioactive compounds reported from $R$. purpurea

\begin{tabular}{|c|c|c|}
\hline Chemical class and compounds & Plant parts & References \\
\hline \multicolumn{3}{|l|}{ Phenolic acids } \\
\hline Gallic acid & Rhizomes & $\begin{array}{l}\text { Singamaneni et al. 2021, Giri et al. } \\
\text { 2017, Rawat et al. 2016c }\end{array}$ \\
\hline Vanillic acid & Tubers & Misra et al. 2015 \\
\hline Protocatechuic acid & Tubers & Misra et al. 2015, Srivastava et al. 2015 \\
\hline 3-Hydroxybenzoic acid & Rhizomes & Giri et al. 2017 \\
\hline Syringic acid & Tubers & Misra et al. 2015, Srivastava et al. 2015 \\
\hline Ellagic acid & Rhizomes & Giri et al. 2017 \\
\hline$p$-Coumaric acid & Rhizomes & Giri et al. 2017, Rawat et al. 2016c \\
\hline Caffeic acid & Rhizomes & Singamaneni et al. 2021 \\
\hline Ferulic acid & Rhizomes & $\begin{array}{l}\text { Singamaneni et al. 2021, Misra et al. } \\
\text { 2015, Srivastava et al. } 2015\end{array}$ \\
\hline 3-Hydroxycinnamic acid & Rhizomes & Giri et al. 2017 \\
\hline Fenozan acid & Rhizomes & Singamaneni et al. 2021 \\
\hline \multicolumn{3}{|l|}{ Flavonoids } \\
\hline Kaempferol & Rhizomes/Tubers & $\begin{array}{l}\text { Singamaneni et al. 2021, Misra et al. } \\
\text { 2015, Srivastava et al. } 2015\end{array}$ \\
\hline Kaempferol 3-O-methyl ether & Aerial parts/ Rhizomes & $\begin{array}{l}\text { Singamaneni et al. 2021, } \\
\text { Miyazaki et al. } 2014\end{array}$ \\
\hline Kaempferol 3-O-glucuronide & Aerial parts & Miyazaki et al. 2014 \\
\hline Kaempferide & Aerial parts/Rhizomes & Miyazaki et al. 2014 \\
\hline Kaempferide 3- $\mathrm{O}$-glucuronide & Aerial parts & Miyazaki et al. 2014 \\
\hline Rutin & Rhizomes & $\begin{array}{l}\text { Giri et al. 2017, Misra et al. 2015, } \\
\text { Srivastava et al. } 2015\end{array}$ \\
\hline Catechin & Rhizomes & Rawat et al. 2016a, , Rawat et al. 2016c \\
\hline Epicatechin & Roots & Kaur et al. 2020a \\
\hline Epigallocatechin & Roots & Kaur et al. 2020a \\
\hline
\end{tabular}




\begin{tabular}{|c|c|c|}
\hline Apigenin & Rhizomes & Srivastava et al. 2015 \\
\hline \multicolumn{3}{|l|}{ Curcuminoid } \\
\hline Bisdemethoxycurcumin & Rhizomes & Singamaneni et al. 2021. \\
\hline \multicolumn{3}{|l|}{ Diterpenoids } \\
\hline Coronarin A & Rhizomes & Singamaneni et al. 2021 \\
\hline Coronarin $\mathrm{K}$ & Rhizomes & Singamaneni et al. 2021 \\
\hline Coronarin L & Rhizomes & Singamaneni et al. 2021 \\
\hline \multicolumn{3}{|l|}{ Other compounds } \\
\hline Lupenone & Roots & Kaur et al. 2020b \\
\hline $\begin{array}{l}\text { (Z)-3-Hexen-1-ol- } \beta \text {-D- } \\
\text { glucopyranoside }\end{array}$ & Aerial parts & Miyazaki et al. 2014 \\
\hline Adenosine & Rhizomes & Miyazaki et al. 2014 \\
\hline
\end{tabular}<smiles>[R]c1cc(C(=O)O)cc([R])c1[R]</smiles>

Gallic acid: $\mathrm{R}_{1}=\mathrm{OH}, \mathrm{R}_{2}=\mathrm{OH}, \mathrm{R}_{3}=\mathrm{OH}$ Protocatechuic acid: $\mathrm{R}_{1}=\mathrm{OH}, \mathrm{R}_{2}=\mathrm{OH}, \mathrm{R}_{3}=\mathrm{H}$ Vanillin acid: $\mathrm{R}_{1}=\mathrm{OCH}_{3}, \mathrm{R}_{2}=\mathrm{OH}, \mathrm{R}_{3}=\mathrm{H}$ 3-Hydroxybenzoic acid: $\mathrm{R}_{1}=\mathrm{OH}, \mathrm{R}_{2}=\mathrm{H}, \mathrm{R}_{3}=\mathrm{H}$ Syringic acid: $\mathrm{R}_{1}=\mathrm{OCH}_{3}, \mathrm{R}_{2}=\mathrm{OH}, \mathrm{R}_{3}=\mathrm{OCH}_{3}$<smiles>CC(C)(C)c1cc(CCC(=O)O)cc(C(C)(C)C)c1O</smiles>

Fenozan acid<smiles>[R17]C1O[C@H]1Oc1c(-c2ccc(O)c(O)c2)oc2cc(O)cc(O)c2c1=O</smiles>

Rutin<smiles>O=c1oc2c(O)c(O)cc3c(=O)oc4c(O)c(O)cc1c4c23</smiles>

Ellagic acid<smiles>[R]c1ccc(/C=C/C(=O)O)cc1[R]</smiles>

p-Coumaric acid: $\mathrm{R}_{1}=\mathrm{H}, \mathrm{R}_{2}=\mathrm{OH}$ Caffeic acid: $\mathrm{R}_{1}=\mathrm{OH}, \mathrm{R}_{2}=\mathrm{OH}$ Ferulic acid: $\mathrm{R}_{1}=\mathrm{OCH}_{3}, \mathrm{R}_{2}=\mathrm{OH}$ 3-Hydroxycinnamic acid: $\mathrm{R}_{1}=\mathrm{OH}, \mathrm{R}_{2}=\mathrm{H}$<smiles>[R20]Oc1ccc(-c2oc3cc(O)cc(O)c3c(=O)c2O[R])cc1</smiles>

Kaempferol: $\mathrm{R}_{1}=\mathrm{H}, \mathrm{R}_{2}=\mathrm{H}$

Kaempferol 3-O-methyl ether: $\mathrm{R}_{1}=\mathrm{CH}_{3}, \mathrm{R}_{2}=\mathrm{H}$ Kaempferol 3-O-glucuronide: $\mathrm{R}_{1}=\mathrm{GlcA}, \mathrm{R}_{2}=\mathrm{H}$ Kaempferide: $\mathrm{R}_{1}=\mathrm{H}, \mathrm{R}_{2}=\mathrm{CH}_{3}$ Kaempferide 3-O-glucuronide: $\mathrm{R}_{1}=\mathrm{GlcA}, \mathrm{R}_{2}=\mathrm{CH}_{3}$<smiles>C=C1[C@H](O)C[C@H]2C(C)(C)CCC[C@]2(C)[C@H]1/C=C/c1ccoc1</smiles>

Coronarin A<smiles>C=C1C(O)CC2C(C)(C)CCC[C@]2(C)C1CC(O)c1ccoc1</smiles>

Coronarin $\mathrm{K}$<smiles>Oc1cc(O)c2c(c1)O[C@H](c1ccc(O)c(O)c1)[C@H](O)C2</smiles>

Catechin<smiles>[R]c1cc([C@H]2Oc3cccc(O)c3C[C@H]2O)cc(O)c1O</smiles>

Epicatechin: $\mathrm{R}=\mathrm{H}$ Epigallocatechin: $\mathrm{R}=\mathrm{OH}$<smiles>O=c1cc(-c2ccc(O)cc2)oc2cc(O)cc(O)c12</smiles>

Apigenin<smiles>O=C(/C=C/c1ccc(O)cc1)CC(=O)/C=C/c1ccc(Br)cc1</smiles>

Bisdimethoxycurcumin<smiles>CC/C=C\CCOC</smiles>

(Z)-3-Hexen-1-ol$\beta$-D-glucopyranoside

Figure 2. Structures of compounds reported from Roscoea purpurea 


\section{Biological activities}

The extracts obtained from $R$. purpurea, mainly rhizomes, are subjected to the evaluation of some biological activities such as antioxidant, antimicrobial, cytotoxic and oxidative DNS damage protecting activities.

The antioxidant properties of the tubers were studied using the 2,2-diphenyl-1-picrylhydrazyl (DPPH) radical scavenging assay and $\beta$-carotene bleaching assay and the $\mathrm{IC}_{50}$ values for the methanolic extract were found to be of $810.66 \pm 1.154$ and $600.66 \pm 1.154 \mu \mathrm{g} / \mathrm{ml}$, respectively (Misra et al. 2015). Rawat et al. (2016a) reported the variation in antioxidant activity of the rhizomes due to geographical and environmental factors based on 2,2'azino-bis(3-ethylbenzothiazoline-6-sulfonic acid) (ABTS), DPPH and ferric reducing antioxidant power (FRAP) assays and suggested that the rhizomes from the plants collected from open grassy lands had higher antioxidant activity. Rawat et al. (2017) also reported the variation in the content of major phenolic contents and antioxidant activity of different phases of life cycle of the plant and suggested that the senescence phase (around November) would be the best phase to collect rhizomes as they had higher content of phenolic compounds and antioxidant activity. Among the different solvent extracts of rhizomes, methanol extract showed highest antioxidant activity (Rawat et al. 2016c). All these studies evaluating the antioxidant activity were based on in-vitro assays and there is necessity of confirming the activity using animal models.

Rawat et al. (2016c) evaluated the antibacterial and antifungal activity of the water, methanol, ethanol, acetone and hexane extracts of rhizomes. These extracts showed variable antibacterial activity against Bacillus subtilis, Staphylococcus aureus, Micrococcus luteus and Escherichia coli. However, these extracts were active only against Candida albicans among the tested fungal species. These activities were limited only to the evaluation zone of inhibition. The determination of minimum inhibitory concentration (MIC) and minimum bactericidal concentration $(\mathrm{MBC})$ is still lacking and future studies should focus on more detailed studies evaluating these parameters.

Few studies have also reported the cytotoxic activities of extracts and compounds against cancer cell lines based on in vitro assays. Cytotoxic activity of methanolic and chloroform extracts of the rhizomes was tested in different human cancer cell lines i.e. lung cancer (A549), breast cancer (MCF-7), colon cancer (HCT-116) and pancreas cancer (Bxpc-3) cells using MTT assay. Both methanolic extract and chloroform extract showed the cytotoxic activities against these cell lines. Compounds isolated from the methanol extract were also tested and coronarin $\mathrm{K}$ showed promising activities (Singamaneni et al. 2021). Srivastava et al. (2015) also reported the cytotoxic activity of ethanol extract and its fractions against A549, human cervical cancer ( $\mathrm{SiHa}$ ), rat glioma (C-6) and Chinese hamster ovary cells (CHOK1) cells. The extract and the petroleum ether fraction showed relatively strong cytotoxic activities.

Giri et al. (2017) reported the potent oxidative DNA damage protecting activity of the $80 \%$ methanol extract of the rhizomes.

There are several other traditional uses such as tonic, would healing, anti-diabetic properties, which are not studies yet for $R$. purpurea. The detailed mechanisms of action of the extracts and bioactive compounds are yet to be elucidated using in vivo and clinical studies.

\section{Conclusion and future perspectives}

The rhizomes of $R$. purpurea are traditionally used as tonic and for the treatment of various diseases/symptoms. However, there no sufficient information about the collection season of the plant, processing methods, preparation of formulations, methods of administration and dosage. Future studies on ethnopharmacological surveys should highlight these aspects. Nutritional and chemical constituent analysis of the rhizomes has revealed the presence many bioactive compounds that are previously reported to have various health beneficial effects such as flavonoids and phenolic acids. It can be a potential source for the development of nutritional products and functional foods. Only a very few biological activity evaluations have been performed and most of them are based on in vitro assays. Regarding antibacterial activities, determination of MIC and MBC is necessary. Similarly, other activities should be evaluated using properly designed in vivo studies. To provide evidence for the therapeutic efficacy as traditional medicine, appropriate clinical studies are necessary. Future studies should focus to fulfil these gaps in research.

\section{Declarations}

Ethics approval and consent to participate: Not applicable.

Consent for publication: This paper does not include any person's data and further permission for publication is not required. 
Availability of data and materials: The data was not deposited in public repositories.

Conflict of interests: The authors declare that they have no competing interests.

Funding: No funding

Authors' contribution: H.P.D. conceived the idea and both contributed to the preparation of first drat and revision. Both authors read, reviewed, and approved the final version of the manuscript.

\section{Literature cited}

Acharya B, Srivastava A, Mishra RK, Patel S, Vashistha RK, Singh A, Jadon V, Saxena P. 2012. Astavarga plants threatened medicinal herbs of the North-West Himalaya. International Journal of Medicinal and Aromatic Plants 2:661-676.

Christenhusz, MJM, Byng JW. 2016. The number of known plants species in the world and its annual increase. Phytotaxa 261:201-217.

Devkota HP, Paudel KR, Hassan MM, Dirar Al, Das N, Adhikari-Devkota A, Echeverría J, Logesh R, Jha NK, Singh SK, Hansbro PM, Chan Y, Chellappan DK, Dua K. 2021. Bioactive Compounds from Zingiber montanum and Their Pharmacological Activities with Focus on Zerumbone. Applied Sciences 11:10205.

Dhyani A, Bahuguna YM, Nautiyal BP, Yadav VK, Chaturvedi P, Nautiyal MC. 2020. Ecological features and traditional knowledge of Roscoea alpina Royle a medicinal plant in Himalaya. Indian Journal of Traditional Knowledge 20:167173.

Ghimire SK, Subedi CK, Budha-Magar S, Adhikari M, Pandey TR, Awasthi B, Thapa Magar S, Paudeyal MR, Ghimire KM, Shrestha BB, Bhatt GD, Joshi LR, Paudel A, Chapagain DJ, Gurung J. 2021. Flora of Kailash Sacred Landscape Nepal: An Annotated Checklist. Volume 1 (Gymnosperms and Angiosperms: Ephedraceae - Buxaceae). Research Centre for Applied Science and Technology (RECAST), Tribhuvan University, Kathmandu, Nepal.

Giri L, Belwal T, Bahukhandi A, Suyal R, Bhatt ID, Rawal RS, Nandi SK. 2017. Oxidative DNA damage protective activity and antioxidant potential of Ashtvarga species growing in the Indian Himalayan Region. Industrial Crops and Products 102: 173-179.

Kaur G, Gupta V, Singhal RG, Rawal RK, Bansal P. 2020a. Isolation of Catechins from Roscoea purpurea. Journal of Young Pharmacists 12(4):389-391.

Kaur G, Gupta V, Bansal P, Kumar S, Rawal RK, Singhal RG. 2020b. Isolation of lupenone (18-Lupen-3-one) from Roscoea purpurea root extract. Bangladesh Journal of Medical Science 19:692-696.

Kumari P, Joshi GC, Tiwari LM. 2011. Diversity and status of ethno-medicinal plants of Almora district in Uttarakhand, India. International Journal of Biodiversity Conservation 3:298-326.

Kunwar RM, Adhikari N. 2005. Ethnomedicine of Dolpa district, Nepal: the plants, their vernacular names and uses. Lyonia 8:43-49.

Lakhan SE, Ford CT and Tepper D. 2015. Zingiberaceae extracts for pain: a systematic review and meta-analysis. Nutrition Journal 14:50.

Misra A, Shrivastava S, Verma S, Rawat AKS. 2015. Nutritional evaluation, antioxidant studies and quantification of poly phenolics, in Roscoea purpurea tubers. BMC Research Notes 8:324.

Miyazaki S, Devkota HP, Joshi KR, Watanabe T, Yahara S. 2014. Chemical constituents from the aerial parts and rhizomes of Roscoea purpurea. The Japanese Journal of Pharmacognosy 68:99-100.

Paudel BR, Shrestha M, Dyer AG, Zhu XF, Abdusalam A, Li QJ. 2015. Out of Africa: evidence of the obgligate mutualism between long corolla tubed plant and long-tunged fly in the Himalayas. Ecology and Evolution 5:52405251.

Rawat S, Andola H, Giri L, Dhyani P, Jugran A, Bhatt ID, Rawal RS. 2014. Assessment of Nutritional and Antioxidant Potential of Selected Vitality Strengthening Himalayan Medicinal Plants. International Journal of Food Properties 17:703-712.

Rawat S, Bhatt ID, Rawal RS, Nandi SK. 2016a. Geographical and environmental variation in chemical constituents and antioxidant properties in Roscoea procera Wall. Journal of Food Biochemistry 41:e12302.

Rawat S, Jugran A, Bhatt ID, Rawal RS, Nandi SK. 2016b. Genetic diversity analysis in natural populations of Roscoea procera Wall. From West Himalaya, India. Brazilian Journal of Botany 29:621-630.

Rawat S, Jugran AK, Bahukhandi A, Bahuguna A, Bhatt ID, Rawal RS, Dhar U. 2016c. Anti-oxidant and anti-microbial properties of some ethno-therapeutically important medicinal plants of Indian Himalayan Region. Biotechnology $6: 154$. 
Rawat S, Jugran AK, Bhatt ID, Rawal RS. 2017. Influence of the growth phenophases on the phenolic composition and anti-oxidant properties of Roscoea procera Wall. in western Himalaya. Journal of Food Science and Technology 55:578-585.

Shah NC. 2019. The History of Botanicals of "Ashtawarga": The most important ingredients used in "Chyawanprash" and the famous rejuvenating tonic of Ayurveda. Journal of Natural \& Ayurvedic Medicine 3:1-14.

Srivastava S, Ankita M, Kumar D, Srivastava A, Sood A, Rawat A. 2015. Reversed-phase high-performance liquid chromatography-ultraviolet photodiode array detector validated simultaneous quantification of six bioactive phenolic acids in Roscoea purpurea tubers and their In vitro cytotoxic potential against various cell lines. Pharmacognosy Magazine 11:S488-95.

Singamaneni V, Lone B, Singh J, Kumar P, Gairola S, Singh S, Gupta P. 2021. Coronarin K and L: Two Novel Labdane Diterpenes from Roscoea purpurea. An Ayurvedic Crude Drug. Frontiers in Chemistry 9:642073.

Timalsina D, Pokhrel KP, Bhusal D. 2021. Pharmacologic Activities of Plant-Derived Natural Products on Respiratory Diseases and Inflammations. BioMed Research International 2021:23.

Tushar, Basak S, Sharma GC, Rangan L. 2010. Ethnomedical uses of Zingiberaceous plants of Northeast India. Journal of Ethnopharmacology 132:286-292.

Watanabe T, Rajbhandari KR, Malla KJ, Devkota HP, Yahara S. 2013. A Handbook of Medicinal Plants of Nepal Supplement I. Ayurseed Life Environmental Institute, Kanagawa, Japan.

Zhao JL, Zhong J, Fan YL, Xia, Li QJ. 2017. A preliminary species-level phylogeny of the alpine ginger Roscoea. Implications for speciation. Journal of Systematics and Evolution 55:215-224. 